\title{
Pemerolehan Bahasa: Kajian Aspek Fonologi Pada Anak Usia 2-2,3 Tahun
}

\author{
Gita Rosi Wulandari ${ }^{1 *}$ \\ ${ }^{1}$ SMP Negeri 229 Jakarta, Jakarta \\ Barat, Jakarta, Indonesia \\ *email: \\ gitarosi.wulandari@gmail.com
}

\begin{abstract}
Abstrak
Penelitian ini menjelaskan pada pemerolehan bahasa anak usia 2 tahun -2 tahun 3 bulan dari segi fonologi. Di pembahasan fonologi yang terdiri dari pemerolehan vokal dan pemerolehan konsonan. Penelitian ini dilakukan pada bulan Oktober-Desember 2019. Penelitian ini menggunakan metode kualitatif memakai pendekatan studi kasus. Sumber data penelitian ini adalah seorang anak laki-laki yang berinisial MADA saat berusia $2-2$ tahun 3 bulan. Data yang didapat disimpan melalui rekaman. Selain melalui proses rekaman, data juga dicatat. Dalam artikel ini dapat ditemukan bahwa pemerolehan fonem [a], [i], [u], [e], [ə], dan [o] MADA sudah dikuasai. Fonem yang pertama MADA kuasai ialah [a], dan [u], sedangkan untuk diftong asli belum dapat dilafalkan. Selain itu, konsonan [p], [m], [b], [y], [s], [n], [k], [d], [c], [t], [n], $[\mathrm{w}],[\mathrm{j}],[\mathrm{g}],[\mathrm{y}]$, dan $[\mathrm{h}]$ sudah mulai dikuasai meskipun masih mengalami kesulitan dalam pengucapan. Fonem yang belum sempurna dikuasai MADA adalah $[\mathrm{r}]$.

Kata kunci: pemerolehan bahasa; fonologi; vokal; konsonan.
\end{abstract}

Received: 24 Januari 2020

Accepted: 16 Maret 2020

Published: 26 Maret 2020

doi:

http://dx.doi.org/10.29405/imj.v2i2

.63

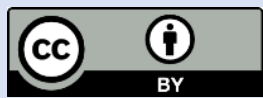

(C) 2020 Oleh authors. Lisensi Imajeri: Jurnal Pendidikan Bahasa dan Sastra Indonesia, Uhamka, Jakarta. Artikel ini bersifat open access yang didistribusikan di bawah syarat dan ketentuan Creative Commons Attribution (CC-BY) license. (http://creativecommons.org/licens es/by/4.0/).

\section{Abstract}

This research explains to the language acquisition of children aged 2 years 2 years 3 months in terms of phonology. In the phonology discussion which consists of vocal acquisition and consonant acquisition. This research was conducted in October-December 2019. This research used a qualitative method using a case study approach. The data source of this study was a boy who had the initials MADA at the age of $2-2$ years and 3 months. The data obtained is stored through recording. Besides going through the recording process, data is also recorded. In this article it can be found that the acquisition of phonemes [a], [i], [u], [e], [a], and [o] MADA has been mastered. The first phonemes of MADA are [a], and [u], while the original diphthong cannot be pronounced. In addition, consonants $[p],[m],[b],[y]$, $[s],[n],[k],[d],[c],[t],[n],[w]],[j],[g],[\eta]$, and $[h]$ have begun to be mastered even though they are still experiencing difficulties in pronunciation. MADA's incomplete phoneme is [r].

Keywords: language acquisition; phonology; vocal; consonants

\section{PENDAHULUAN}

Setiap manusia pasti melakukan komunikasi melalui bahasa. Bahasa adalah lambang bunyi untuk menyampaikan sesuatu yang bermakna. Selain sebagai alat komunikasi, bahasa juga bisa menjadi jembatan antargenerasi sehingga menimbulkan komunikasi berkesinambungan. Pada dasarnya, bayi yang baru dilahirkan sudah mulai menunjukkan keinginannya berkomunikasi, misalnya dengan tangisan karena merasa haus, lapar, atau pun mengantuk. Untuk kebutuhan komunikasinya, anak-anak selalu memperhatikan juga meniru 
setiap kata yang diucapkan orang dewasa terutama orang tua. Dalam perkembangannya, ketika anak ada di posisi tahapan pemerolehan bahasa pertamanya terdapat faktor yang bisa mempengaruhi, yakni internal dan eksternal. Faktor internal bisa dilihat dalam diri seseorang terutama pada kecerdasannya, dan faktor eksternal yang mempengaruhi ialah lingkungan, yakni keluarga atau pun lingkungan sekitar yang dapat membantu dalam tahap pemerolehan bahasa anak.

Pemerolehan bahasa adalah penguasaan bahasa pada diri seseorang tanpa sadar. Seperti pendapat Kiparsky (dalam Tarigan, 1998) berpendapat tentang pemerolehan bahasa merupakan cara anak saat melakukan penyesuaian tentang kaidah tata bahasa berdasarkan ucapan orang tua. Stork dan Widdowson (1974) menjelaskan pemerolehan bahasa merupakan cara seorang anak dalam lancarnya berbicara pada bahasa ibu. Huda (1987) juga berpendapat mengenai pemerolehan bahasa, yakni kemampuan seseorang dalam menguasai bahasa terjadi dengan alamiah. Jadi, bisa dikatakan bahwa pemerolehan bahasa adalah penguasaan bahasa yang proses terjadinya di alam bawah sadar seseorang. Pemerolehan bahasa berbeda dengan pembelajaran bahasa. Pemerolehan murni didapat tanpa pengaruh dari pembelajaran bahasa itu sendiri.

Membicarakan teori pemerolehan bahasa, maka terdapat empat teori yang mengemukakan tentang pemerolehan bahasa, yaitu 1) teori behaviorisme, 2) kognitivisme, 3) nativisme, dan 4) interaksionisme. Pemerolehan bahasa yang baik adalah jika orang tua selalu mengajak berkomunikasi anaknya. Dengan begitu, kosa kata yang diperoleh anak akan semakin kaya. Hal ini juga dikatakan oleh teori behaviorisme, yaitu dalam berperilaku bahasa harus adanya rangsangan dan reaksi (stimulus-response). Jika seorang anak melafalkan sebuah kata tanpa ada pembenaran dari orang tua, maka si anak menganggap bahwa kata yang dilafalkan sudah benar. Tapi jika anak tersebut melafalkan fonem yang salah, maka ada reaksi dari orang tua untuk membenarkan. Sehingga anak lebih mengetahui bahwa itu harus diperbaiki dalam pelafalannya.

Manusia dapat menghasilkan sebuah bahasa. Bahasa itu sendiri dihasilkan oleh alat ucap manusia. Hal ini sependapat dengan teori nativisme dari Chomsky, yaitu hanya manusialah yang bisa berbahasa, sedangkan binatang tidak dapat berbahasa seperti manusia. Karena bahasa berasal dari alat ucap manusia, maka ilmu yang mempelajarinya adalah fonologi. Fonologi merupakan bagian dari ilmu linguistik yang fokus kajiannya mengenai bunyi bahasa. Seperti pendapat Ahmad HP (2013) bahwa fonologi merupakan bagian dari bidang linguistik yang fokus kajiannya mengenai tata cara bunyi bahasa.

Di tataran linguistik, fonologi adalah sebuah kajian yang paling dasar. Fonologi pun memiliki tataran terkecil yang menjadi fokus kajiannya, yaitu fonem. Fonologi terbagi menjadi dua, yakni fonetik dan fonemik. Fonetik merupakan bagian fonologi yang berfokus pada kajian bunyi bahasa. Sedangkan fonemik adalah bagian dari fonologi yang mengkaji tentang pembeda makna di setiap bunyi bahasa.

Pita suara dapat mengeluarkan bunyi-bunyi bahasa. Saat terbuka, pita suara yang ada di rongga mulut pasti menghasilkan suara, yaitu bunyi bahasa. Proses ini bisa disebut dengan artikulasi. Sudah dikatakan sebelumnya bahwa bayi yang baru lahir sudah menunjukkan keinginan komunikasi. Tetapi pada usia bayi (0-6 bulan) belum dapat mengeluarkan bunyi bahasa yang berarti. Hal ini disebabkan karena belum berfungsinya artikulator dengan baik. Begitu pula pada usia 6 - 12 bulan yang hanya terdengar celotehan-celotehan yang tidak bermakna. Pada usia inilah anak memperoleh dan mencoba menirukan setiap bunyi bahasa yang ia dengar. Sedangkan memasuki tahun pertama, anak sudah mulai melafalkan kata-kata yang bermakna. Hal ini seiring dengan pendapatnya Ervin Tripp (dalam Samsunuwiyati, 2005) yang mengatakan bahwa di tahun pertama anak sudah dapat membedakan bunyi-bunyi dan hal ini bisa dilihat pada interaksi anak dengan lingkungannya. 
Pemerolehan tentang bahasa anak sangat banyak, seperti pada penelitian yang dilakukan oleh Prima Gusti Yanti dari FKIP UHAMKA. Penelitiannya membahasa tentang fonologi anak usia 2 - 2 tahun 6 bulan yang dilakukan pada anak kandungnya berinisial TPM. Hasilnya TPM sudah menguasai fonem vokal maupun konsonan dengan baik. Untuk fonem vokal yang pertama dikuasai yaitu [i], [u], dan [a]. pada fonem konsonan, hambat lebih dulu dikuasai sebelum frikatif, sedangkan frikatif sudah dikuasai sebelum afrikatif.

Selain itu, ada penelitian dari Ida Hamidah dari SPS UHAMKA. Peneltiannya mengenai akuisis bahasa anak usia 3 tahun 5 bulan. Penelitiannya dilakukan terhadap anak dengan inisial PM. Hasilnya, PM sudah menunjukkan penguasaannya terhadap huruf mati [b], $[\mathrm{g}],[\mathrm{t}],[\mathrm{f}],[\mathrm{y}],[\mathrm{h}],[\mathrm{n}],[\mathrm{k}],[\mathrm{p}],[\mathrm{m}],[\mathrm{j}],[\mathrm{l}],[\mathrm{r}],[\mathrm{d}],[\mathrm{s}],[\mathrm{w}]$, dan $[\mathrm{c}]$ di usianya 3 tahun 4 bulan. Untuk fonem vokal, PM telah menguasainya lebih dahulu. Namun, masih ada beberapa fonem konsonan yang masih belum terlihat atau terdengar jelas, misalnya pada konsonan yang letaknya di akhir kata.

Kemudian penelitian R. Hery Budhiono dari Balai Bahasa Provinsi Kalimantan Tengah yang membahasa pemerolehan fonologis anak usia $0-2$ tahun. Penelitian ini dilakukan terhadap seorang anak yang bernama Mia. Hasilnya, Mia lebih dahulu menguasai vokal [a] dibanding vokal lainnya, sedangkan vokal lainnya dikuasai kemudian. Ia mengatakan bahwa dalam pemerolehan bahasa terdapat tiga faktor. Pertama, adanya masukan bahasa. Kedua, kepekaan terhadap lingkungan. Ketiga, interaksi atau komunikasi.

Artikel ini membahasa tentang fonologi yang diperoleh MADA pada usia 2 tahun sampai 2 tahun 3 bulan meliputi pemerolehan vokal dan konsonan. Di usia ini adalah masa kritis, di mana pemerolehan bahasa sangat penting dan berpengaruh terhadap penguasaan bahasa anak.

Berdasarkan penjelasan di atas, artikel ini menjelaskan tentang proses anak mendapatkan bahasanya dari segi fonologi. Hal ini dapat dirumuskan sebagai batasan masalah pada: (a) bagaimana pemerolehan vokal terhadap anak usia 2 tahun -2 tahun 3 bulan?, (b) bagaimana pemerolehan konsonan terhadap anak usia 2 tahun -2 tahun 3 bulan?

\section{METODE}

Penelitian ini menggunakan metode kualitatif melalui pendekatan studi kasus. Dalam mekanismenya akan dijelaskan tentang perkembangan bahasa MADA terutama dalam bidang fonologi. Penelitian dilakukan saat MADA usia $2-2$ tahun 3 bulan. Desain penelitian ini yaitu longitudinal, ialah proses mengamati dari satu titik tertentu sampai ke titik yang lain. Sumber data di penelitian ini yakni anak laki-laki yang berinisial MADA saat berusia $2-2,3$ tahun. MADA merupakan anak kandung penulis. Data-data yang dikumpulkan selama tiga bulan berdasarkan catatan, observasi, dan wawancara terhadap orang tua juga kakek dan nenek MADA. Dari hasil observasi dan wawancara itu kemudian direkam dan dicatat. Semua data kemudian ditranskrip lalu dianalisis dan ditelaah secara empiris. Selanjutnya data yang sudah diperoleh, penulis kelompokan sesuai dengan permasalahan pada fokus penelitian ini.

\section{HASIL DAN PEMBAHASAN}

MADA adalah seorang anak laki-laki yang aktif dan cerdas. Sama seperti dengan anak-anak lain seusianya, MADA juga memiliki rasa ingin tahu yang tinggi. Keingintahuannya berkembang seiring berjalannya waktu sesuai pertambahan usianya. Begitu pun dalam hal pemerolehan bahasa. MADA tidak mengalami kesulitan berkomunikasi dengan orang tua atau pun lingkungan sekitar walaupun masih harus banyak belajar dalam pelafalan. Hal tersebut terbukti dalam jumlah kosa kata MADA yang semakin bertambah dan semakin jelas dalam pelafalan sebuah kata. Di usia ini, MADA sudah bisa melafalkan sebuah kata 
sesuai dengan makna yang dilambangkannya. Misalnya, saat ia melihat sebuah kereta api lalu berkata [tutut]. MADA melambangkan sebuah kereta api dengan kata [tutut] karena ia teringat dengan bunyi klakson kereta api.

\section{Pemerolehan Vokal}

Bunyi vokal dalam pemerolehan bahasa MADA selama pengamatan 3 bulan adalah sebagai berikut:

Fonem [a] adalah huruf vokal pertama yang dikuasai MADA. Di vokal ini, sudah dikuasainya dengan sangat baik mulai di awalan kata, tengah, juga akhir. Untuk awalan, vokal [a] terlihat di kata:

[a] [aja] 'aja' dan [abang] 'abang'

Vokal [a] yang ada di tengah terdapat pada kata:

[a] [mamam] 'mamam' dan [buang] 'buang'

Selanjutnya, vokal [a] yang muncul di akhir adalah:

[a] [iya] 'iya' dan [bua] 'dua'

Selain vokal [a], vokal [i] juga sudah dilafalkan sangat baik oleh MADA, baik di depan, antarhuruf, dan belakang. Bunyi fonem [i] yang ada di depan terdapat di:

[i] [itat] 'ikan' serta [iya] 'iya'

Vokal [i] yang di tengah terlihat di kata:

[i] [naik] 'naik' dan [didi] 'gigi'

Kemudian vokal [i] yang terletak pada akhir kata:

[i] [api] 'api' dan [adi] 'lagi'

Pada bunyi vokal [u] juga sudah bisa diucapkan oleh MADA dengan baik. Bunyi vokal [u] berada di awal terdapat pada kata:

$$
[\mathrm{u}][\mathrm{uu}] \text { 'ungu' }
$$

Vokal $[u]$ yang letaknya di tengah kata seperti:

[u] [pupu] 'kupu-kupu' dan [duduk] 'duduk'

Vokal $[\mathrm{u}]$ yang letaknya di akhir adalah:

$$
\text { [u] [tsutsu] 'susu' }
$$

Kemudian pada bunyi vokal [e] sudah bisa diucapkan sangat lantang, baik yang posisinya di depan, antarhuruf, dan belakang. Bunyi [e] yang di depan kata adalah sebagai berikut:

[e] [enak] 'enak'

Sedangkan vokal [e] di tengah kata terlihat di kata:

[e] [embe] 'ember'

Bunyi vokal [e] yang letaknya di akhir kata terdapat pada: 
[e] [kue] 'kue'

Untuk bunyi vokal [ə] pun sudah jelas dilafalkan oleh MADA baik di depan, antarhuruf, serta belakang kata. Pada awal kata huruf [ə] terdapat pada kata:

[ə] [ənam] 'ənam'

Lalu fonem vokal [ə] yang berada di tengah seperti di contoh kata:

[ə] [bewom] 'bəlum'

Vokal [o] telah mampu dilafalkan secara lancar dan tegas. Untuk huruf bagian depan, bisa terlihat sebagai berikut:

[o] [owang] 'orang' dan [ote] 'oke'

Bunyi vokal [o] yang ada di tengah kata terdapat pada:

[o] [kowah] 'sekolah' dan [otok] 'gosok'

Vokal [o] yang terletak di akhir kata terdapat pada kata:

[o] [tawo] 'taro' dan [ino] 'dino'

Pada pelafalan vokal rangkap sudah mulai terdengar jelas. Seperti pada vokal [ue]. [au]. Dan [ua]. Vokal ganda [ue] terdapat di kata:

[ue] [kue] 'kue'

Vokal ganda [au] terdengar jelas terdapat di kata:

[au] [paus] 'paus' dan [daun] 'daun'

Sedangkan vocal rangkap [ua] terdapat di kata:

[ua] [uang] 'uang' dan [buang] 'buang'

Tabel 1. Pemerolehan Vokal pada Usia 2 - 2,3 Tahun

\begin{tabular}{|c|c|c|c|}
\hline Vokal & Depan & Antarhuruf & Belakang \\
\hline$/ \mathrm{a} /$ & $\sqrt{ }$ & $\sqrt{ }$ & $\sqrt{ }$ \\
\hline /i/ & $\sqrt{ }$ & $\sqrt{ }$ & $\sqrt{ }$ \\
\hline$/ \mathrm{u} /$ & $\sqrt{ }$ & $\sqrt{ }$ & $\sqrt{ }$ \\
\hline$/ \mathrm{e} /$ & $\sqrt{ }$ & $\sqrt{ }$ & - \\
\hline$/ \mathrm{a} /$ & $\sqrt{ }$ & $\sqrt{ }$ & $\sqrt{ }$ \\
\hline /o/ & $\sqrt{ }$ & & \\
\hline
\end{tabular}

Tabel tersebut bisa ditarik kesimpulan, yakni MADA sudah dapat melafalkan huruf [a], [i], [u], [e], [ə], dan [o] secara teratur dan lancar. Semua vokal sudah muncul atau dilafalkan MADA di ketiga posisi, baik di awal, tengan maupun di akhir. Dalam pemerolehan 
fonem vokal tersebut MADA tidak mengalami hambatan yang dapat membuat ia kesulitan pada pelafalannya. Fonem vokal tersebut sudah dikuasai MADA diusianya 2 tahun.

Pada saat pengamatan dilakukan, fonem vokal yang bersifat diftong asli belum terlihat. Dengan kata lain, MADA belum dapat melafalkan vokal yang berbentuk diftong seperti [au] dan [ai].

\section{Pemerolehan Konsonan}

Setelah penjabaran pemerolehan vokal, MADA yang hampir tidak ada hambatan. Berbeda dengan pemerolehan fonem konsonan. Dalam hal ini MADA masih ada beberapa huruf yang pelafalannya belum jelas bahkan hilang saat pengucapan suatu kata. Nampaknya, pada pelafalan konsonan tersebut MADA mengalami kesulitan.

Bunyi konsonan bilabial seperti $[\mathrm{b}],[\mathrm{p}],[\mathrm{m}]$, dan $[\mathrm{w}]$ sudah mulai terdengar jelas walaupun ada beberapa huruf yang berubah atau bersubsitusi dengan huruf lain seperti pada kata:

[b] [batuk] 'batuk' dan [abang] 'abang'

[p] [pipis] 'pipis' dan [puwang] 'pulang'

Walaupun fonem [p] sudah mulai dapat dilafalkan oleh MADA, tapi pada kata 'panas' menjadi [manas].

[m] [makan] 'makan' dan [mau] 'mau'

[w] [wah] 'wah'

Selain konsonan bilabial yang masih ada kesulitan dalam pelafalan, pada konsonan laminopalatal seperti [1], dan [s], pun terdapat kesulitan dalam pengucapan. Seperti pada kata berikut ini:

Setiap konsonan [1] yang berada di awal kata hampir tidak dapat dilafalkan misalnya kata:

[adi] 'lagi'

[əраs] 'ləpas'

Bunyi konsonan [1] yang ada di tengah bersubtitusi dengan fonem [w] seperti:

[gəwap] 'gəlap'

[bawon] 'balon'

Bunyi konsonan [1] yang berada di akhir kata sama seperti berada di awal, sama-sama tidak terdengar dan menjadi hilang. Contohnya:

$$
\begin{aligned}
& \text { [apə] 'apol' } \\
& \text { [mbi] 'mobil' }
\end{aligned}
$$

Untuk konsonan [s] tidak jauh berbeda dengan konsonan [1]. dipengucapan konsonan [s] ini MADA masih merasa kesulitan saat pelafalannya. Bunyi konsonan [s] yang letaknya di awal seperti:

$$
\begin{aligned}
& \text { [tsutsu] 'susu' } \\
& \text { [kiap] 'siap' }
\end{aligned}
$$




$$
\text { [cemut] 'semut' }
$$

Kemudian konsonan [s] yang ada di tengah kata:

$$
\begin{aligned}
& \text { [itang] 'pisang' } \\
& \text { [majid] 'masjid' }
\end{aligned}
$$

Bunyi konsonan [s] di akhir kata lebih jelas pelafalannya di banding di awal dan tengah kata, terlihat pada kata:

[awas] 'awas

[manas] 'panas'

Konsonan frikatif [h] lebih dahulu dikuasai MADA dibanding afrikatif [j]. Namun demikian, huruf konsonan frikatif $[\mathrm{h}]$ juga ada yang sulit diucapkan sehingga menghilangkannya. Misalnya:

[ebat] 'hebat'

[idung] 'hidung'

Konsonan [h] yang berada di akhir nampaknya lebih mudah untuk dilafalkan, terdapat pada kata :

[ayah] 'ayah'

[meyah] 'merah'

Pada penjabaran di atas, terlihat bahwa MADA sudah dapat menguasai bahkan melafalkan beberapa fonem konsonan. Konsonan tersebut adalah $[\mathrm{p}],[\mathrm{m}],[\mathrm{b}],[\mathrm{y}],[\mathrm{y}],[\mathrm{s}]$, $[\mathrm{n}],[\mathrm{k}],[\mathrm{d}],[\mathrm{c}],[\mathrm{t}],[\mathrm{h}],[\mathrm{w}],[\mathrm{j}],[\mathrm{n}]$, dan $[\mathrm{g}]$ yang sudah mulai jelas diucapkan pada usia 2 tahun 3 bulan. MADA pun masih kesulitan dalam pengucapan kata yang terdiri dari tiga suku kata. Contohnya pada kata:

'sekolah' menjadi [kowah]

'kepala' menjadi [pawa]

'pesawat' menjadi [cawat]

\section{SIMPULAN}

Pemerolehan bahasa terutama fonologi MADA secara umum sesuai dengan teori pemerolehan. MADA lebih cepat menguasai huruf vokal dibanding huruf konsonan. Huruf vokal yang pertama MADA kuasai adalah [a], dan [u]. selanjutnya vokal-vokal yang lain semakin lama semakin jelas pengucapannya. Dalam huruf konsonan pula MADA mulai menguasai. Konsonan yang paling awal dikuasai adalah bilabial [p], dan [m]. Namun demikian, MADA masih kesulitan di beberapa fonem konsonan baik yang letaknya di awal, tengah, atau pun akhir kata. Oleh sebab itu, dalam pelafalannya terkadang bersubtitusi dengan huruf lain atau menjadi hilang dan tak terdengar saat diucapkan. Contohnya fonem [1] yang berada di awal dan di akhir menjadi hilang. Begitu pula fonem [1] yang letaknya di tengah berubah menjadi fonem [w]. sama seperti fonem [1], konsonan [h] pun demikian, tetapi saat 
letaknya di tengah belum terlihat. MADA juga masih belum menguasai pengucapan secara jelas jika kata tersebut terdiri dari tiga suku kata. Misalnya di kata [sekolah] menjadi [kowah], [pesawat] menjadi [cawat]. Semua dipenggal menjadi dua suku kata. MADA juga masih kebingungan saat dihadapkan fonem konsonan rangkap, seperti kata [tunggu] menjadi [tudu], [bunda] menjadi [da], [tangan] menjadi [tanan].

\section{DAFTAR PUSTAKA}

Arsanti, Meilan. (2014). Pemerolehan Bahasa Pada Anak (kajian Psikolinguistik). Jurnal PBSI Vol. 3, No. 2 Universitas Islam Sultan Agung

Budhiono, R. Hery. (2011). Pemerolehan Fonologis Pada Anak Usia 0-2 Tahun. Adabiyyat Vol. 10, No. 1 Balai Bahasa

Brown, H. Douglas. (2008). Prinsip Pembelajaran dan Pengajaran Bahasa, edisi kelima. Jakarta: Kedutaan Besar Amerika Serikat

Dardjowidjojo, Sunjono. (2010). Psikolinguistik: Pengantar Pemahaman Bahasa Manusia. Jakarta: Yayasan Obor Indonesia

HP, Achamd dan Alek Abdullah. (2013). Linguistik Umum. Jakarta: Erlangga

Mar'at, Samsunuwiyati. (2005). Psikolinguistik (Suatu Pengantar). Bandung: Refika Aditama Marsono. (1986). Fonetik. Yogyakarta: Gadjah Mada University Press

Tarigan, Henry Guntur. (1998). Pengajaran Pemerolehan Bahasa. Jakarta: Direktorat Pendidikan Tinggi, Departemen Pendidikan dan Kebudayaan

Tim Penyusun. (2017). Modul Pengembangan Keprofesian Berkelanjutan. Kementerian Pendidikan dan Kebudayaan

Yanti, Prima Gusti. (2016). Pemerolehan Bahasa Anak: Kajian Aspek Fonologi Pada Anak Usia 2 - 2,5 Tahun. Jurnal Ilmiah VISI PPTK PAUDNI - Vol. 11, No. 2 UHAMKA. 